\title{
An Investigation of the Antecedents of Organizational Citizenship Behaviour: Case of Saudi Arabia
}

\author{
Anwar Rasheed $^{1,2}$, Khawaja Jehanzeb ${ }^{1,2} \&$ Mazen F. Rasheed ${ }^{3}$ \\ ${ }^{1}$ Department of Management, College of Business Administration, King Saud University, Riyadh, Saudi Arabia \\ ${ }^{2}$ FPPSM, Universiti Teknologi Malaysia, Johar, Malaysia \\ ${ }^{3}$ Department of Public Administration, College of Business Administration, King Saud University, Riyadh, \\ Saudi Arabia \\ Correspondence: Anwar Rasheed, Department of Management, College of Business Administration, King Saud \\ University, Riyadh 11587, Saudi Arabia. Tel: 966-550-902-061. E-mail: anrasheed@ksu.edu.sa
}

Received: January 22, 2013

Accepted: February 27, $2013 \quad$ Online Published: March 1, 2013

doi:10.5539/ijps.v5n1p128

URL: http://dx.doi.org/10.5539/ijps.v5n1p128

\begin{abstract}
Organizational Citizenship Behaviour (OCB) has been signified as one of the antecedents of organizational effectiveness. OCB is widely studied over the years in the US but has received relatively inadequate attention in other Asian contexts. This study explored and examined number of predictors of OCB in the Arabic-speaking context (Saudi Arabia in Gulf). The data was drawn from 275 employees of both private and public banking sectors. Predictors of OCB examined are Job Satisfaction and Organizational Commitment, Role Perceptions, Fairness Perceptions, Leadership Behavior, Individual Dispositions, Motivation and Feedback. The results found support the hypotheses stating the positive relationship between the predictors of OCB and organizational citizenship behaviour except motivation that found no relationship with OCB. Implications for future research are discussed.
\end{abstract}

Keywords: Organizational Citizenship Behavior (OCB), job satisfaction, performance, banking sector, Saudi Arabia

\section{Introduction}

OCB reveals that the behavior is cooperative with the organization but it is not the condition for an official job. It is the matter of individual to select the OCB but failure to do this is not punished. In recent years, the topic of organizational citizenship behaviour has been adequately researched and these behaviors help effective functioning of the organization (Podsakoff, Ahearne and MacKenzie 1997; Podsakoff and MacKenzie 1994). Numerous measures and OCB dimensions have been explored such as altruism, sportsmanship, loyalty, civic virtue, voice, conscientiousness, functional participation, courtesy and advocacy participation (Bateman and Organ 1983; William and Anderson 1991; VanDyne, Graham and Dienesch 1994). However, there are five measures of OCB that are well documented in research (LePine, Erev and Johnson 2002). These are altruism (helping colleagues who have heavy workload), conscientiousness (punctuality at work), sportsmanship (willingness to tolerate less than perfect circumstances without complaining), courtesy (notify before taking any actions), and civic virtue (attends functions which are not important, but helps the image of the organization).

Most of the studies on OCB have been conducted in North America (Farh, Early and Lin 1997). But the dimension of OCB has acknowledged relatively incomplete attention in other frameworks (Paille 2009). Podsakoff et al. (2000) argue that research on OCB dimension in other cultural context is important. Further Podsakoff explained cultural background may affect the kinds of citizenship behavior which are observed in organization. The past research has described the affiliation between organizational citizenship behaviour and the variables of employee attitude. Research has revealed that organizational citizenship behavior assists in maximizing the performance of the organization (Podsakoff et al., 2000). Every organization tries to understand the importance of organizational citizenship behavior and how OCB affects the performance of the organizations. This understanding will help the managers to evaluate which type of environment needed for employees to motivate and stratified them.

Association between the predictors of employees' attitude and organizational citizenship behaviour have been 
researched in the past (Erturk, 2007), for the present study, researchers explored and examined number of predictors of OCB based on the discussion of the dimensions of OCB. Predictors of OCB examined are Job Satisfaction and Organizational Commitment, Role Perceptions, Fairness Perceptions, Leadership Behavior and LMX, Individual Dispositions, Motivation and Feedback. The inspiration of this research is to extend the existing literature on organizational citizenship behaviour by investigating the predictors of employee attitude which relate to employees who are working in the bank situated in the Saudi Arabia.

\section{Literature Review}

\subsection{Organizational Citizenship Behavior}

As defined by Organ (1988), OCB referred to some discretionary behavior of individuals' that are unrecognized by direct or explicit formal reward system and promotes the effective functioning of the organization in aggregate. OCB represents a behavior beyond routine expectations (Joireman et al. 2006). Primarily, Katz (1964) presented the term of OCB on extra role behaviors. Organ and Bateman (1983) added into the understanding of OCB and they concluded in it by calling it "the good soldier syndrome" (Organ, 1988). There is influential evidence that OCB is the outcome, consistent with a social exchange relationship (Deckop et al. 1999). Walz and Niehoff (1996) argued that OCB elaborates a set of desirable organizational behaviors that illustrate multi-dimensional relationships with positive organizational outcomes. Organizational Citizenship Behavior (OCB) can contribute to organizational effectiveness and success in numerous ways (MacKenzie et al., 1991; Organ, 1988; Podsakoff and MacKenzie, 1994; Smith et al., 1983).

OCB has gained a considerable amount of research concentration in both organisational behaviour and social psychology to determine the individuals' engagement in this (McNeely and Meglino, 1994). OCB has been studied in various disciplines including marketing, economics and human resource management. This prevalent attention towards OCB based on the findings that OCB leads to improved organizational effectiveness (Podsakoff and MacKenzie, 1994; Podsakoff, Ahearne, and MacKenzie, 1997). Beyond adding to employee and organizational performance, OCB also changes the way a manager evaluates the employees (Organ, 1990). Organ (1988) stated that OCB is held to be an important to the survival and wellbeing of an organization. Employees with citizenship behaviors are more likely to obtain support from their organizations (Moorman et al. 1998). Organ (1988) identified altruism, conscientiousness, sportsmanship courtesy and civic virtue as the five particular categories of discretionary behaviors that can improve the employees' efficiency in the organization. Nevertheless, researchers have found many other predictors of OCB including leader characteristics and quality of an employee's relationship with his leader (Podsakoff et. al, 1996), procedural justice (Moorman, 1991; Aquino, 1995), personality (Organ, 1990; Penner et al., 1997), motivational theories (Kemery et al., 1996) job satisfaction Bateman and Organ 1983), perceptions of fairness (Folger, 1993; Tepper and Taylor, 2003) and commitment (O'Reilly and Chatman, 1986). Though, numerous studies have been conducted regarding OCB some researchers (e.g., Pond et al. 1997) argued that OCB as an extra role behaviour that is not formally measured.

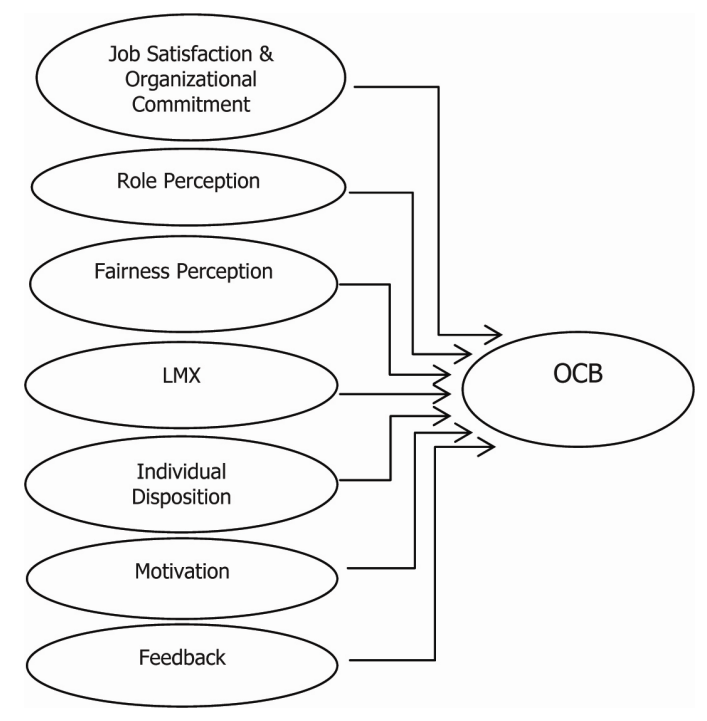

Figure 1. Hypothesized model of predictors of organizational citizenship behaviour 


\subsection{Job Satisfaction and Organizational Commitment}

Job satisfaction has been studied by many researchers in various contexts and one of them is OCB. Werner (2007) argued that satisfied employees are more likely to exhibit positive behaviors that can increase the overall functioning of the organization. Brown (1993) asserted that high level of job satisfaction among employees leads to contribute more towards citizenship behaviors. The strongest attitudinal relationship exists between job satisfaction and OCB (Organ and Ryan, 1995). Oishi et al., (1999) claimed that job satisfaction is related to intrinsic motivation. Satisfied employees would seemingly be more expected to have a positive word of mouth about the organization, help others, and perform higher than goals at their job. In a study of two large banks conducted by Smith et al (1983) to investigate job satisfaction-OCB relationship examined a positive correlation between job satisfaction and OCB. Similarly, Ahmed, Rasheed and Jehanzeb (2012) also found the positive relationship between job satisfaction and OCB. Moorman et al (1993) emphasized the effects of job satisfaction, organizational commitment and procedural justice on OCB and explained that both organizational commitment and job satisfaction would not be related to OCB when the procedural justice-OCB relationship controlled. Organizational commitment is understood as a strong belief in accomplishing the organizational goals and to play a vital part in the organization (Van Dyne et al., 1995).

Hypothesis 1: Job satisfaction and organizational commitment will be positive predictor of organizational citizenship behaviour.

\subsection{Role Perception}

Roles in the organization, serve to function in the role of coordinating individual behaviors (Katz and Kahn, 1978). Nevertheless, perceived roles differ may lead to role stress. Role perceptions include both perceptions of role conflict and role ambiguity which have been found to be negatively related to OCB. Conversely, role clarity and role facilitation are positively related (Podsakoff et al., 2000). Role uncertainty or role ambiguity is the reverse situation (Jansen and Gaylen, 1994). This suggests that role ambiguity negatively and significantly affects OCB. Further, as both role ambiguity and role conflict are identified to affect employee satisfaction whereas satisfaction is related to $\mathrm{OCB}$, it is likely that some percentage of the relationship between ambiguity, conflict and OCB is mediated by satisfaction.

\section{Hypothesis 2: Role perception will be positive predictor of organizational citizenship behaviour.}

\subsection{Fairness Perception}

Fairness or justice perceptions refer to employee's perception of organizational decisions are made equitably or not also known as procedural justice and whether or not employees feel that they are fairly rewarded given their level of training or workload known as distributive justice. Organ (1990) asserts that fairness perceptions play a major role in creating organizational citizenship behavior. This is because, if employees perceive fairness to be treated, they are more likely to respond the fair treatment that their organization offers them. If employees feel fair treatment in their organization, they are more expected to adopt citizenship behavior as significant part of the social exchange (Moorman, 1991). Therefore, we expect the following relationship.

Hypothesis 3: Fairness Perceptions may have a positive relationship with organizational citizenship behaviour.

\subsection{Leader-Member Exchange}

Leader member exchange (LMX) refers to the differentiated relationship between a leader and a subordinate (Martin et al., 1999). Leadership seems to have a strong influence on subordinate's willingness to engage in OCB. Nevertheless, rather than being associated with a theoretical leadership style, research discovers that it is the quality of a leader's relationship with his or her subordinate that counts (Podsakoff et al., 2000). Numerous studies found positive relationships between LMX and OCB, which is one of the important outcome variables of LMX relationship (Deluga, 1998; Podsakoff, MacKenzie, Paine, Bachrach, 2000; Wayne, Shore, and Liden, 1997) Leadership behaviors probably, influence OCB indirectly via employee's perception of fairness in the workplace. This is in line with the arguments of Rousseau (1995) that employees mostly consider their direct supervisors as the chief agent and the representation of the organization's commitment to them.

\section{Hypothesis 4: Leader-Member Exchange will be positive predictor of organizational citizenship behaviour.}

\subsection{Individual Disposition}

Dispositional factors such as personality possibly important individual difference variables for OCB researchers. Bateman and Organ (1983) stated the reason of personality might predict OCB was that people with certain personality traits might have higher propensity to be satisfied with their job whereas people with other personality traits are likely to be less satisfied. Attitudinal factors such as inclination toward job satisfaction 
might cause the connection between personality and OCB (Organ and Ryan, 1995; Smith et al., 1983). Though, Borman et al. (2001) proposed that only conscientiousness and agreeableness exhibit steady effects on OCB. However, personality may be a considerable measure in order to control for its influence on behaviour or to examine any apparent moderating effects on OCB. Failure to identify individual motivational factors might lead to more dissatisfaction, turnover and low performance (Kahn et al. 1964; Sun, Aryee and Law, 2007).

Hypothesis 5: Individual dispositions will be positive predictor of organizational citizenship behaviour.

\subsection{Motivation}

Organ (1990) proposed that an individual's motives may relate to his or her organizational citizenship behaviors. Penner et al. (1997) discovered the impact of motivation on OCB: value expressiveness knowledge (self-concept) and (goal internalization). According to Piccolo and Colquitt (2006) findings, follower intrinsic motivation is positively related to follower task performance and organizational citizenship behavior. Many researchers found that employee's motivation is considerably associated to his or her organizational citizenship behavior (Finkelstein and Penner, 2004; Tang and Ibrahim, 1998). Allen and Rush (1998) stated that the leader's perception of follower's motives is more likely to influence the employee's OCB rating. Thus a significant relationship is anticipated between employee OCB and their sources of motivation.

Hypothesis 6: Motivation will be positive predictor of organizational citizenship behaviour.

\subsection{Feedback}

Feedback is largely acknowledged invaluable within organizations particularly in managing employee behaviour but only a few studies have examined the relationship between feedback and OCB. The earliest study found was Funderburg and Levy (1997) who discovered no significant relationships between feedback and OCB. Nonetheless, Bacharach, Bendoly, and Podsakoff (2001) found a relationship between feedback and civic virtue along with between feedback and helping behavior. Another study of Klein (2003) reinforced the concept by indicating that providing feedback on achievements may lead employees to involve in positive social behaviors. Therefore, based on the increasing significance of feedback for managers and employees, present researchers propose that when feedback is given to employees about both formal and informal performance, they are likely to increasing their formal performance and OCB in future. This idea is also in line with the study by Erez (1977) who emphasized the contribution of feedback beyond any standard goal setting strategy.

\section{Hypothesis 7: Feedback will be positive predictor of organizational citizenship behaviour.}

\section{Method}

\subsection{Participants and Procedures}

The research operated in the banking sector of Riyadh, Saudi Arabia. Random sampling was used to collect the data from the employees available in the office hours or break time from diverse departments from both managerial and non-managerial roles. 400 questionnaires were personally distributed of which 290 respondents returned the questionnaires (response rate of $72.5 \%$ ). To ensure legitimacy, haphazard responses to reverse-scored distracter items and questionnaires with blank items omitted and finally 275 questionnaires selected for analysis.

Demographics of respondents in Table 1 shows $50 \%$ belong to age less than 30 years and $37.5 \%$ between 31 to 40 years. Gender profile of participants represented $82.2 \%$ male and $17.8 \%$ were female. $87.3 \%$ respondents were graduated with Bachelor's or higher degree. Respondents nationalities were diversified with $93 \%$ Saudi and remaining non-Saudi citizens. Banking sector in recent years has taken immense actions to ensure Saudization that leads to fewer numbers of expatriates. 
Table 1. Demographics

\begin{tabular}{|c|c|c|c|}
\hline & Description & No. & Percent \\
\hline \multirow{2}{*}{ Gender } & Male & 226 & 82.2 \\
\hline & Female & 49 & 17.8 \\
\hline \multirow{4}{*}{ Age } & Less than 30 years & 137 & 49.8 \\
\hline & $31-40$ years & 103 & 37.5 \\
\hline & $41-50$ years & 26 & 9.5 \\
\hline & Over 50 years & 9 & 3.2 \\
\hline \multirow{4}{*}{ Tenure } & Less than 1 year & 49 & 17.8 \\
\hline & 1 to 2 years & 70 & 25.5 \\
\hline & 3 to 5 years & 77 & 28.0 \\
\hline & Over 5 years & 79 & 28.7 \\
\hline \multirow{4}{*}{ Qualification } & Less than Bachelors & 35 & 12.7 \\
\hline & Bachelors & 187 & 68.0 \\
\hline & Masters & 49 & 17.8 \\
\hline & Higher than Masters & 4 & 1.5 \\
\hline \multirow{2}{*}{ Nationality } & Saudi & 255 & 93.0 \\
\hline & Non-Saudi & 20 & 7.0 \\
\hline
\end{tabular}

\subsection{Measures}

Five point Likert-scale was used in the questionnaire for all the measures where $1=$ strongly disagree and $5=$ strongly agree. Moreover, personal identification of respondents was avoided to ensure anonymity. The scales adopted in this study were developed in English; therefore, to guarantee cross-linguistic quality, we translated all measures into Arabic and then translated them again into English by two bilingual (English-Arabic) professional translators (Brislin, 1980).

OCB was measured using the15-item scale developed by Motowidlo and Van Scotter (1994). Cronbach reliability was reported .95 in the study of Motowidlo and Van Scotter (1994). Job satisfaction was measured using scale of Hackman and Oldham (1980) and the shortened version of Organizational Commitment Questionnaire (OCQ) developed by Mowday, Steers and Porter (1979) is used with 4 items to measure organizational commitment. Role perception to assess the degree of clarity was measured with 10-item scale of Sawyer's (1992). However, most frequently used scale developed by Niehoff and Moorman (1993) was adapted to measure general fairness perception with two sub-scales, distributive justice and procedural justice.

The 7-item scale developed by Scandura and Graen (1984) was used to measure Leader-member relationship. Items included for LMX questioned subordinates the level of quality exchange with their supervisor. Coefficient alpha for the scale reported was .89. Work motivation behaviour scale of the Akinboye's (2001) was adapted to measure motivation level of the employees. Finally, Russell and Goode's (1988) four items measure was adapted for perception of feedback among employees. Sample item was "My last feedback gave me a good idea of how well I'm doing my job'.

\subsection{Statistical Analysis}

The data entered and analysed by using Statistical Package for Social Sciences (SPSS) software. The test for significance " $t$ " test, coefficient of correlation by using Pearson's Method and multiple regression analysis were executed to test the hypothesis. 
Table 2. Means, standard deviations, partial correlations, and coefficient alphas of study variables

\begin{tabular}{|c|c|c|c|c|c|c|c|c|c|c|}
\hline Variables & Mean & SD & 1 & 2 & 3 & 4 & 5 & 6 & 7 & 8 \\
\hline 1. OCB & 3.73 & .66 & $(.80)$ & & & & & & & \\
\hline $\begin{array}{l}\text { 2. Job Satisfaction } \\
\text { and Organizational } \\
\text { Commitment }\end{array}$ & 3.96 & .75 & $.53^{* *}$ & $(.92)$ & & & & & & \\
\hline 3. Role Perception & 3.70 & .84 & $.34 * *$ & $.28 * *$ & $(.79)$ & & & & & \\
\hline $\begin{array}{l}\text { 4.Fairness } \\
\text { Perception }\end{array}$ & 3.30 & .98 & $.07 *$ & .17 & $.48^{* *}$ & $(.91)$ & & & & \\
\hline 5. LMX & 3.93 & .72 & $.39 * *$ & $.38^{* *}$ & $.39 * *$ & $.40^{* *}$ & (.89) & & & \\
\hline $\begin{array}{l}\text { 6.Individual } \\
\text { Disposition }\end{array}$ & 3.43 & .72 & $.26^{* *}$ & .16 & .07 & .12 & $.35^{* *}$ & $(.88)$ & & \\
\hline 7. Motivation & 4.12 & .88 & $.36^{*}$ & .37 & $.31 * *$ & $.42 * *$ & $.51^{* *}$ & $.30^{* *}$ & $(.80)$ & \\
\hline 8. Feedback & 3.97 & .80 & $.29^{* *}$ & $.37 * *$ & .09 & $.25^{* *}$ & $.20 *$ & $.21 *$ & .03 & $(.89)$ \\
\hline
\end{tabular}

Note: $* *=$ Correlation is significant at the .01 level $\mathrm{p}<.01$ (2-tailed); $*=$ Correlation is significant at the .01 level $\mathrm{p}<.01$ (2-tailed); $\mathrm{N}=275$

Table 3. Multiple regression analyses of various predictors of model and their interactions with $\mathrm{OCB}(\mathrm{N}=275)$

\begin{tabular}{lllll}
\hline Variable & $\beta$ & \multirow{2}{*}{ S.E } & t- value & P \\
& Standardized Coefficient & & & \\
\hline Job Satisfaction and Organizational Commitment & .38 & .072 & 4.28 & .000 \\
Role Perception & .24 & .067 & 2.82 & .006 \\
Fairness Perception & .26 & .059 & 2.73 & .007 \\
LMX & .13 & .084 & 1.42 & .050 \\
Individual Disposition & .13 & .071 & 1.69 & .015 \\
Motivation & .15 & .072 & 1.44 & .154 \\
Feedback & .36 & .073 & 4.278 & .000 \\
\hline
\end{tabular}

$\mathrm{R}^{2}=.41$

\section{Results}

Correlations between the determinants of OCB and the employees' organizational citizenship behaviour is tested and shown in Table 2. Standardized Cronbach's alpha for every variable reflects sufficient internal consistency reliability coefficients for all the variables that is greater than .75 (Nunnally, 1978). Means and standard deviations of the seven identified variables which can affect OCB are also presented. Maximum correlation ( $\mathrm{r}$ $=.53)$ was found between job satisfaction and organizational commitment and $\mathrm{OCB}$ at $(\mathrm{p}<.01)$ significance level.

Table 3 shows the regression analysis of the predictors of OCB and their multiple interactions with OCB controlling for demographics. Job satisfaction \& commitment-OCB relationship was established to be strongly significant $(\beta=.38$, t-value $=4.28, \mathrm{p}=.000)$ that supported our hypothesis 1 . Hypothesis 2 predicted that role perception is positively related to OCB. As shown in Table 3, role perception had significant relationship with $\operatorname{OCB}(\beta=.24, \mathrm{p}<.01)$, so hypothesis 2 was supported. Although, fairness perception was least but significantly correlated $(\mathrm{r}=.07)$ with OCB to accept our hypothesis 3 . The results in Table 3 further revealed the extent to which LMX significantly regress the OCB $(\beta=.13, \mathrm{p}<.05)$ to accept the hypothesis 4 . Hypothesis 5 predicted that individual disposition will positively affect the OCB was supported by results $(\beta=.13, p<.05)$.

Contrary to our expectations, hypothesis 6 did not find any support from results as insignificant relationship was found between motivation and OCB ( $\mathrm{p}>.05)$. Finally, present study also explored and investigated feedback along with the previously studied variables that could impact organizational citizenship behavior. Feedback 
reflected to be strongly significant $(\beta=.36$, t-value $=4.278, \mathrm{p}=.000$ ) which is supported by our hypothesis. Furthermore, the relative magnitude of these bi-variate correlations is consistent with fundamental theory and predictions.

\section{Discussion}

The study investigated and found the positive relationship among the identified predictors of OCB to determine the magnitude of OCB in the banking sector of Saudi Arabia. Gautam et al. (2005) stated that with a change in geographic context, citizenship behaviour of employees may also differ. Thus, examination of the predictors of OCB makes a lot of sense in gulf countries like Saud Arabia where organizations in the banking sector are facing numerous challenges. However, in general, our results of study reconfirmed the results of studies conducted in dissimilar context of USA and Pakistan (e.g., Rioux \& Penner, 2001; Kashif, Khan \& Rafi, 2011).

The results of our study showed the positive significant relationship between job satisfaction \& commitment and OCB are consistent with the previous studies e.g., Brown (1993) who also found the significant relationship between job satisfaction, commitment and OCB. Similarly, role perception was analysed to be positively significant and linked with OCB which is in line with the previous findings (e.g., Podsakoff et al., 2000) who argued role clarity and role facilitation are positively related to OCB whereas role conflict and role ambiguity have been negatively related to OCB. According to Podsakoff et al. (2010) leader's behaviour is associated with OCB of employees which is also evident in this study with the findings of significant relationship. Another variable projected by Organ and Ryan (1995) used in this study was individual disposition that affirmed previous results of positive relationship with OCB.

Contrary to our hypothesis, results found the non-significant relationship between motivation and OCB $(\mathrm{p}>.05)$. This shows that motivation does not impact organizational citizenship behaviour of employees in the banking sector of Saudi Arabia. Although, the findings are dissimilar to our hypothesis yet Harrell (2008) also found the insignificant relationship between motivation and OCB. There are prospects to study the relationship of motivation-OCB in different contexts for future research in this area.

Feedback along with the previously studied variables was also investigated in this study that may influence OCB and showed significant results. Thus, our findings showed that effective feedback procedure leads to employee's participation in extra roll activities. Therefore supervisors and management need to provide constructive feedback to the employees to achieve organizational goals through both formal and informal (day-to-day) feedback.

\section{Conclusion}

This study emphasizes the importance of OCB which is equally helpful for organizations and employees. Predictors of OCB are the factors that fluctuate the level of employees' performance in an organization. Our study along with various empirical studies has exposed a positive relationship between OCB and its predictors (e.g., Cardona et al., 2004; Hodson, 2002). Motivation depicted insignificant results in our study but another variable which is not yet much studied linked to OCB is feedback that shows effective feedback procedure may lead to employee's organizational citizenship behavior. Consistent with our theoretical framework, this research strongly indicates the influence of particular predictors of OCB. Organizations can benefit from the current study by knowing the significance of the predictors of $\mathrm{OCB}$, and how they impact such behavior, is valuable for both managers and employees of every organization.

\section{References}

Ahmed, N., Rasheed, A., \& Jehanzeb, K. (2012). An Exploration of Predictors of Organizational Citizenship Behaviour and its Significant Link to Employee Engagement. International Journal of Business, Humanities and Technology, 2(4), 99-106.

Akinboye, J. O. (2001). Executive behaviour battery. Ibadan: Stirling-Horden Publishers.

Allen, T. D., \& Rush, M. C. (1998). The effects of organizational citizenship behavior on performance judgments: A field study and a laboratory experiment. Journal of Applied Psychology, 83, 247-260. http://dx.doi.org/10.1037/0021-9010.83.2.247

Aquino, K. (1995). Relationships between pay inequity, perceptions of procedural justice and organizational citizenship. Emp. Responsib. Rights J., 8, 21-33. http://dx.doi.org/10.1007/BF02621253

Bachrach, D. G., Bendoly, E., \& Podsakoff, P. M. (2001). Attributions of the "causes" of group performance as an alternative explanation of the relationship between organizational citizenship behavior and

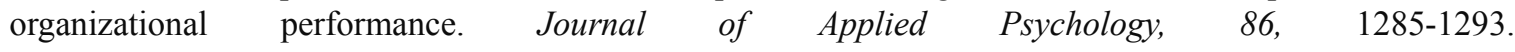


http://dx.doi.org/10.1037/0021-9010.86.6.1285

Bateman, T. S., \& Organ, D. W. (1983). Job satisfaction and the good soldier: The relationship between affect and employee "citizenship". Academy of Management Journal, 26, 587-595. http://dx.doi.org/10.2307/255908

Boonzaaier, B., Ficker, F., \& Rust, B. (2001). A review of research on the Job Characteristics Model and the attendant job diagnostic survey. South African Journal of Business Management, 32(1), 11-29.

Borman, W. C., Penner, L. A., Allen, T. D., \& Motowidlo, S. J. (2001). Personality predictors of citizenship performance. International Journal of Selection and Assessment, 9(1/2), 52-69. http://dx.doi.org/10.1111/1468-2389.00163

Brislin, R. W. (1980). Translation and content analysis of oral and written material. In H. C. Triandis \& J. W. Berry (Eds.), Handbook of Cross-Cultural Psychology (Vol 2, pp. 389-444). Boston: Allyn and Bacon.

Brown, R., (1993). Antecedents and consequences of salesperson job satisfaction: Meta-analysis and assessment of causal effects. J. Mark. Res., 30, 63-77. http://dx.doi.org/10.2307/3172514

Cardona, P., Lawrence, B. S., \& Peter M. B. (2004). The Influence of Social and Work Exchange Relationships on Organizational Citizenship Behavior. Group and Organization Management, 29, 219-247. http://dx.doi.org/10.1177/1059601103257401

Deckop, J. R., Mangel, R., \& Circa, C. (1999). Getting More Than You Pay For: Organizational Citizenship and Pay-Performance Plans. Academy of Management Journal, 42, 420-428. http://dx.doi.org/10.2307/257012

Deluga, R. J. (1998). Leader-member exchange quality and effectiveness ratings: the role of subordinate-supervisor conscientiousness similarity. Group and Organization Management, 23(2), 189-216. http://dx.doi.org/10.1177/1059601198232006

Erez, M. (1977). Feedback: A necessary condition for goal setting-performance relationship. Journal of Applied Psychology, 62, 624-627. http://dx.doi.org/10.1037/0021-9010.62.5.624

Ertruk, A. (2007). Increasing organizational citizenship behaviors of Turkish academicians: Mediating role of trust in supervisor on the relationship between organizational justice and citizenship behaviors. Journal of Managerial Psychology, 22(3), 257-270. http://dx.doi.org/10.1108/02683940710733089

Farh, J., Earley, P. C., \& Lin, S. (1997). Impetus for action: A cultural analysis of justice and organizational citizenship behavior in Chinese society. Administrative Science Quarterly, 42, 421-444. http://dx.doi.org/10.2307/2393733

Finkelstein, M. A., \& Penner, L. A. (2004). Predicting Organizational Citizenship Behavior: Integrating the functional and role identity approaches. Social Behavior and Personality, 32, 383-398. http://dx.doi.org/10.2224/sbp.2004.32.4.383

Folger, R. (1993). Justice, motivation, and performance beyond role requirements. Employee Responsibilities and Rights Journal, 6, 239-248. http://dx.doi.org/10.1007/BF01419447

Funderburg, S. A., \& Levy, P. E. (1997). The influence of individual and contextual variables on 360-degree feedback system attitudes. Group and Organizational Studies, 22(2), 210-230. http://dx.doi.org/10.1177/1059601197222005

Gautam, et al. (2005). Organizational Citizenship Behavior and Organizational Commitment in Nepal. Asian Journal of Social Psychology, 8, 305-314. http://dx.doi.org/10.1111/j.1467-839X.2005.00172.x

Gautam, T., Van Dick, R., Wagner, U., Upadhyay, N., \& Davis, A. J. (2005). Organizational Citizenship Behavior and Organizational Commitment in Nepal. Asian Journal of Social Psychology, 8, 336-345. http://dx.doi.org/10.1111/j.1467-839X.2005.00172.x

Hackman, J. R., \& Oldham, G. R. (1980). Work redesign. Reading, MA: Addison-Wesley.

Harrell, M. M. (2008). The Relationships Between Leader Behavior, Follower Motivation, And Performance. Unpublished doctoral dissertation, University of Central Florida Orlando, Florida.

Hodson R. (2002). Management Citizenship Behavior and Its Consequences. Work and Occupations, 29(1), 64-96. http://dx.doi.org/10.1177/0730888402029001004

Jansen E., \& Gaylen G. N. (1994). Innovation and restrictive conformity among hospital employees: individual outcomes and organizational considerations. Hosp. Health Serv. Adm., 39(1), 63-80. 
Joireman, J., Daniels, D., Falvy, J., \& Kamdar, D. (2006). Organizational Citizenship Behavior as Function of Empathy Consideration of Future Consequences, And Employee Time Horizon: An Initial Exploration Using An In-Basket Simulation of OCBs. Journal of Applied Social Psychology, 36(9), 2266-2292. http://dx.doi.org/10.1111/j.0021-9029.2006.00103.x

Kahn, R., Wolfe D., Quinn, R., \& Snoek, J. (1964). Organisational stress: studies in role conflict and ambiguity. London: Wiley.

Kashif, M., Khan, Y., \& Rafi, M. (2011). An Exploration of the Determinants of OCB in the Telecommunication Sector of Pakistan. Asian Journal of Business Management, 3(2), 91-97.

Katz, D., \& Kahn, R. L. (1978). The Social Psychology of Organizations. New York: Wiley.

Katz, D. (1964). The motivational basis of organizational behavior. Behavioral Science, 9, 131-133. http://dx.doi.org/10.1002/bs.3830090206

Kemery, E. R., Bedeian, A. G., \& Zacur, S. R. (1996). Expectancy-based job cognitions and job affects as predictors of organizational citizenship behavior. J. Appl. Soc. Psychol., 26, 635-651. http://dx.doi.org/10.1111/j.1559-1816.1996.tb02735.x

Klein, W. M. P. (2003). Effects of objective feedback and single other or average other social comparison feedback on performance judgments and helping behavior. Personality and Social Psychology Bulletin, 29, 418-429. http://dx.doi.org/10.1177/0146167203251195

Lee, K., \& Allen, N. J. (2002). Organizational citizenship behavior and workplace deviance: The role of affect and cognitions. Journal of Applied Psychology, 87, 131-142. http://dx.doi.org/10.1037/0021-9010.87.1.131

LePine, J. A., Erez, A., \& Johnson, D. E. (2002). The nature and dimensionality of OCB: A critical review and meta-analysis. Journal of Applied Psychology, 87, 52-65. http://dx.doi.org/10.1037/0021-9010.87.1.52

MacKenzie, S. B., Podsakoff, P. M., \& Fetter, R. (1991). Organizational citizenship behavior and objective productivity as determinants of managerial evaluations of salespersons' performance. Organizational Behavior and Human Decision Processes, 50, 123-150. http://dx.doi.org/10.1016/0749-5978(91)90037-T

Martin, D. F., Taylor, R. R., O'Reilly, D., \& McLaurin, R. J. (1999). The effect of trust on leader-member exchange relationships in two national contexts. Presented at the Southern Academy of Management Conference. Atlanta, GA.

McNeely B. L., \& Meglino B. M. (1994). The role of dispositional and situational antecedents in prosocial organisational behaviour: An examination of the intended beneficiaries of prosocial behaviour. J. Appl. Psychol., 79(6), 836-844. http://dx.doi.org/10.1037/0021-9010.79.6.836

Moorman R. H. (1993). Fairness in performance monitoring: The role of justice in mediating the relationship between monitoring and organizational citizenship behaviors. Acad. Manage. J., 36, 527-556. http://dx.doi.org/10.2307/256591

Moorman, R. H., Blakely, G. L., \& Niehoff, B. P. (1998). Does perceived organizational support mediate the relationship between procedural justice and organizational citizenship behavior? Academy of Management Journal, 41, 351-357. http://dx.doi.org/10.2307/256913

Moorman, R. (1991). Relationship between organizational justice and organizational citizenship behaviors: Do fairness perceptions influence employee citizenship? Journal of Applied Psychology, 76, 845-855. http://dx.doi.org/10.1037/0021-9010.76.6.845

Motowidlo, S. J., \& Van Scotter, J. R. (1994). Evidence that task performance should be distinguished from contextual performance. Journal of Applied Psychology, 79, 475-480. http://dx.doi.org/10.1037/0021-9010.79.4.475

Mowday, R., Steers, R., \& Porter, L. (1979). The measurement of organizational commitment. Journal of Vocational Behavior, 14, 224-247. http://dx.doi.org/10.1016/0001-8791(79)90072-1

Nunnally, J. C. (1978). Psychometric theory (2nd ed.). New York: McGraw-Hill.

Niehoff, B. P., \& Moorman, R. H. (1993). Justice as a mediator of the relationship between methods of monitoring and organizational citizenship behavior. Academy of Management Journal, 36, 527-556. http://dx.doi.org/10.2307/256591

O'Reilly, C., \& Chatman, J. (1986). Organizational commitment and psychological attachment: the effects of compliance, identification, and internalization on pro-social behavior. Journal of Applied Psychology, 7 , 
492-499. http://dx.doi.org/10.1037/0021-9010.71.3.492

Oishi, S., Diener, E., Lucas, R., \& Eunkook S. (1999). Cross-cultural variations in predictors of life satisfaction: Perspectives from needs and values. Pers. Soc. Psychol. Bull., 25, 980-990. http://dx.doi.org/10.1177/01461672992511006

Organ, D. W., \& Ryan, K. (1995). A meta-analytic review of attitudinal and dispositional predictors of

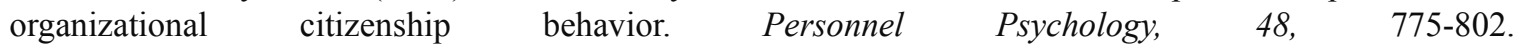
http://dx.doi.org/10.1111/j.1744-6570.1995.tb01781.x

Organ, D. W. (1988). Organizational Citizenship Behavior: The Good Soldier Syndrome. Lexington, MA.

Organ, D. W. (1990). The motivational basis of organizational citizenship behavior. Research in Organizational Behavior, 12, 43-72.

Paille, P. (2009). Assessing organizational citizenship behavior in the French Context: Evidence for the Four-Dimension Model. The Journal of Psychology, 143(2), 133-147. http://dx.doi.org/10.3200/JRLP.143.2.133-146

Penner, L. A., Midili, A. R., \& Kegelmeyer, J. (1997). Beyond job attitudes: A personality and social psychology perspective on the causes of organizational citizenship behavior. Human Performance, 10(2), 111-131. http://dx.doi.org/10.1207/s15327043hup1002_4

Piccolo, R. F., \& Colquitt, J. A. (2006). Transformational leadership and job behaviors: The mediating role of core job characteristics. Academy of Management Journal, 49, 327-340. http://dx.doi.org/10.5465/AMJ.2006.20786079

Podsakoff, P. M., \& MacKenzie, S. B. (1994). Organizational citizenship behaviors and sales unit effectiveness. Journal of Marketing Research, 3, 351-363. http://dx.doi.org/10.2307/3152222

Podsakoff, P. M., Ahearne, M., \& MacKenzie, S. B. (1997). Organizational citizenship behavior and the quantity and quality of work group performance. Journal of Applied Psychology, 82, 262-270. http://dx.doi.org/10.1037/0021-9010.82.2.262

Podsakoff, P. M., MacKenzie, S. B., \& Bommer, W. H. (1996). Transformational leader behaviors and substitutes for leadership as determinants of employee satisfaction, commitment, trust and organizational citizenship behaviors. Journal of Management, 22, 259-298.

Podsakoff, P. M., MacKenzie, S. B., Paine, J. B., \& Bachrach, D. G. (2000). Organizational citizenship behaviors: A critical review of the theoretical and empirical literature and suggestions for future research. Journal of Management, 26, 513-564. http://dx.doi.org/10.1177/014920630002600307

Rioux, S. M., \& Penner, L. A. (2001). The causes of organizational citizenship behavior: a motivational analysis. Journal of Applied Psychology, 86, 1306-1314. http://dx.doi.org/10.1037/0021-9010.86.6.1306

Rousseu, D. M. (1995). Psychological Contract in Organizations. Thousand Oaks, CA: Sage.

Russell J, S., \& Goode, D, L. (1988). An analysis of manager's reactions to their own performance appraisal feedback. Journal of Applied Psychology, 73, 63-67. http://dx.doi.org/10.1037/0021-9010.73.1.63

Sawyer, J. E. (1992). Goal and process clarity: Specification of multiple constructs of role ambiguity and a structural equation model of their antecedents and consequences. Journal of Applied Psychology, 77, 130-142. http://dx.doi.org/10.1037/0021-9010.77.2.130

Scandura, T. A., \& Graen, G. (1984). Moderating effects of initial leader-member exchange status on the effects of a leadership intervention. Journal of Applied Psychology, 71, 579-584. http://dx.doi.org/10.1037/0021-9010.71.4.579

Smith, C. A., Organ, D. W., \& Near, J. P. (1983). Organizational citizenship behavior: Its nature and antecedents. Journal of Applied Psychology, 68, 653-663. http://dx.doi.org/10.1037/0021-9010.68.4.653

Sun, L. Y., Aryee, S., \& Law, K. S. (2007). High-performance human resource practices, citizenship behavior, and organizational performance: A relational perspective. The Academy of Management Journal Archieve, 50(3), 558-577. http://dx.doi.org/10.5465/AMJ.2007.25525821

Tang, T. L., \& Ibrahim, A. H. (1998). Antecedents of organizational citizenship behavior: Public personnel in the United States and in the Middle East. Public Personnel Management, 27, 529-548.

Tepper, B. J., \& Taylor, E. C. (2003). Relationship among supervisors' and subordinates' procedural justice perceptions and organizational citizenship behaviors. Academy of Management Journal, 46, 97-105. 
http://dx.doi.org/10.2307/30040679

Van Dyne, L., Cummings, L. L., \& Parks, J. M. (1995). Extra-role behaviors: In pursuit of construct and definitional clarity (A bridge over muddied waters). In L. L. Cummings \& B. M. Staw (Eds.), Research in Organizational Behavior (Vol. 17, pp. 215-285). Greenwich, CT: JAI Press.

Walz, S. M., \& Niehoff, B. P. (1996). Organizational citizenship behaviors and their effect on organizational effectiveness in limited menu restaurants (pp. 307-311). Best Paper Proceedings, Academy of Management Conference.

Wayne, S. J., Shore, L. M., \& Liden, R. C. (1997). Perceived organizational support and leader-member exchange: a social exchange perspective. Academy of Management Journal, 40(1), 82-111. http://dx.doi.org/10.2307/257021

Werner, A. (2007). Organisational Behaviour: A Contemporary South African Perspective. Pretoria: Van Schaik Publishers.

Williams, L. J., \& Anderson, S. E. (1991). Job satisfaction and organizational commitment as predictors of organizational citizenship and in-role behaviors. Journal of Management, 17(3), 601-617. http://dx.doi.org/10.1177/014920639101700305 